\title{
The State Policy of Education in Modern Russia: Pro and Contra
}

\author{
Marina Starodubtceva and Irina Krivko
}

\begin{abstract}
Various educational initiatives of Russian government make the study of the state educational policy important in recent years. The report shows the main principles and the organizational base of the state policy in education, reviews its positive moments. Special attention is paid to the state initiative of building the new system of education. In addition, the report shows few controversies in the state educational policy that gives a rise to public discussions in modern Russia.
\end{abstract}

Index Terms-Education, law, society, state policy.

\section{INTRODUCTION}

In modern Russia education is a problem that worries a lot along with issues, such as, social split on rich and poor, unavailability of medical service and a high flow of immigrants and newcomers. The social surveys of the Analytical Center of Urey Levada discovered that $72 \%$ of Russians were dissatisfied by modern educational system in Russia. $38 \%$ of Russians believe that the quality of the education became worse during the last year, and $41 \%$ think that it did not change. In addition, the negative attitude to the educational quality has increased by $6 \%$ in comparison with a previous year. $39 \%$ of Russians say that they cannot get a good education today. $31 \%$ say about poor educational quality in Russia.

Russians are especially worried about general secondary education. The studies of Analytical Center of Urey Levada show the following serious problems of the general secondary education: increase of the payment, disproportion between the payment and educational quality, poor educational quality (hence there is no opportunity to get to the university and get a good job), poor professional level of the teachers, and bad material conditions of schools. In whole $49 \%$ of Russians appraise the modern educational system as "satisfactory," $19 \%$ - "good," $23 \%$ - "bad (very bad)." $36 \%$ of Russians believe that the state "carries out its duties and at the same time, it does not" particularly in educational sphere. $27 \%$ think that the state "does not carry out its duties anymore." $12 \%$ believe that the state "does not do it at all" [1].

The low quality and a decrease of social services availability in educational sphere are acknowledged by the government, and are considered to be a negative tendency in

Manuscript received October 25, 2013; revised December 26, 2013.

Marina Starodubtceva is with the Theology and Religion Studies Department, Kursk State University, Kursk, Russian Federation (e-mail: maristarva@gmail.com).

Irina Krivko is with the Department of Foreign languages, Kursk State University, Kursk, Russian Federation (e-mail: irin-krivko@yandex.ru). human development potential and should be solved. Thus, the main goal of the state policy in educational sphere is an achievement of the new quality of the Russian education. It is defined by the correspondence to the topical and perspective demands of Russia's modern life and helps the society to develop in a positive way. It is obvious that this government position shows its readiness to implement educational policy and to strengthen its influence in educational management, and that is a modern trend all over the world nowadays [2].

Government educational policy represents various government actions, concerning supply, functioning and development of educational system. In educational policy we can define different aspects, which characterize its elements, correlations between them, forms and features of their implementation. These aspects are: political, ideological, social, moral, legislative and confessional. The most important between them are legislative and organizational aspects [3].

Further in the text we perceive government policy as a system of conceptual ideas and principles established by the state power. It is a base for the development of legislative documents, regulation the functioning of the state educational institutions and the plans for the application of these conceptual positions in education.

\section{PRINCIPLES AND IDEAS}

Government educational policy is based on the principles and ideas that provide its development. The principles are written in the Russian Federation Constitution and in legislative acts that provide legal regulation of educational sphere.

According to the Constitution, the state guaranties the right for education, free and accessible preschool education, basic and secondary professional education at state or public institutions and enterprises. The state guaranties every citizen the right of getting a university education on a competitive base. In addition, the state provides accessible secondary education. The state has the right to establish federal state educational standards and to support different educational and self-educational forms.

Two main federal laws that determine the principles of modern educational policy are: the law On Education 1992 and the law On Education 2012. The first group includes the principles that represent the political and philosophic paradigm of the society. They are: overall democratization of the education, pluralism, variability, alternatives, regional character, national self-determination of schools, accessibility. The second group includes the principles that provide the foundation and the mechanisms to implement the 
new pedagogical paradigm. They are: humanization, and differentiation of education, developing character and continuity [4]. Hereby, the federal legislation declares these principles, making them a legal norm, and determines the way of education development, as the leading social institute.

National Doctrine of Education in the Russian Federation till 2025 is the main government's concept, as one of the valuable social forces. Education plays a vital role in historical succession of generations, preservation, distribution and development of national culture, harmonization of national and ethno-cultural relations, preservation and support of ethnic identity of nations in Russia and their humanistic traditions and cultures, and preservation of languages and culture of Russian folks. Taking all these into consideration, the Doctrine declares the main ideas that represent the basis of education content: historically formed moral values, modern scientific outlook, inter-national and inter-ethnic relations.

\section{ORGANIZATIONAL BASE}

Organizational base is an important part of government educational policy. It determines the goals, the objectives, the content of educational policy, the means and ways of its implementation.

The following documents are offering the organizational base of the state policy of the Russian Federation in the educational sphere:

1) The Conception of Russian Education Modernization till 2010.

2) The Federal Special-Purpose Program of Educational Development from 2011 till 2015.

3) The priority national project "Education."

4) The national educational initiative "Our New School."

The Federal Special-Purpose Program of Educational Development from 2011 till 2015 includes the actions that the state is going to carry out in educational sphere.

Program actions are divided into three areas: modernization of pre-school and general secondary education, bringing the content and the structure of the professional education to the needs and requirements of labour-market, and the development of the quality evaluation system of education. Modernization is an important mean to overcome stagnation in educational policy that was evident at the beginning of the new century [5].

Modernization of pre-school and general secondary education is considered to be the most important. It includes the following actions:

1) Provision with new educational programs for general education.

2) Establishment of the quality management system of pre-school and general secondary school.

3) Establishment of the organizational and financial model of upgrading professional skills.

4) Making the model of state-society management in education.

5) Producing the system of cooperation between universities and institutes of secondary education.

Within a scope of bringing the content and the structure of the professional education to respond the requirements of labour-market the state plans to realize the following actions:

1) Development and implementation of modernization program of professional educational system.

2) Realization of complex regional programs of professional education development.

3) Implementation of new economic mechanisms in educational management.

4) Unification of the professional educational institutes.

5) Training and professional development of educators in Information and Computing Technology (ICT).

The development of the quality evaluation system of education and the demand of educational services consists of the following actions:

1) Development and implementation of a new model of quality evaluation system of general secondary education.

2) Formation of a unified informational system of educational sphere.

3) Forming the system of public and professional accreditation of the educational programs.

Those actions will provide the availability of high quality education and realize the main principle of the state educational policy.

\section{Positive ACHIEVEMENTS}

Despite the fact that the state educational policy has a huge public outcry today, including negative opinions, we should acknowledge its positive effects. They are the following: state guarantees an education of every citizen, no discrimination in educational sphere, guarantee of rights and freedom of all the participants of educational process (parents, learners, and educational workers). The state guarantees a right on education during the whole life according to the demands of a learner, a right to study a native language and a right to choose a language of studies among the languages of nations living in Russia.

The learners are supplied with various rights: a concern to their psyche-physical state, participation in forming of the content of their professional education, a choice of elective courses, freedom of conscience, information, and thought expression, a participation in education management, incentives for participation in different activities (sport, studies, public life, and creativity). According to the educational legislation, students get social support: providing school students with meal, giving scholarships, financial aid, giving loans on education.

The parents (legal representatives) of under-age students have a right to give their child preschool, primary and secondary education at home, to be acquainted with educational curriculum, methods of teaching, and to participate in educational management.

The educators have a right and a freedom to teach, to choose methods of teaching, and express their creative initiative. They can develop and launch their own educational programs and methods, participate in educational management, and they have a right for protection of their educational honour and dignity.

The state supports disabled people, talented and creative students, gives financial aid for those, who need social 
protection during their studies.

Upbringing is considered to be a significant point in government educational policy. National Doctrine of Education in the Russian Federation till 2025 points out educational goal at school as the primary one. The Doctrine points out the importance of physical, moral, labour, civil, legal, ecological upbringing and also the importance of national and religious tolerance. The law On Education 2012 described education as an activity aimed at the personality development, providing the conditions for self-determination and socialization of a learner on the bases of socio-cultural, spiritual and moral values, and according to public norms of behavior for the benefit of family, society and state interests [6]. In this connection, educational programs of primary school consists of special subjects, focused on the knowledge about spiritual bases and culture of the Russian Federation, moral principles, historical and cultural traditions of the world religion, and alternative subjects. Parents or legal representatives of the learners can choose only one subject (course or module) in accordance with their wishes. This position observes the constitutional right to choose upbringing.

Since April 2010 the Ministry of Education and Science of the Russian Federation has included the subject Foundations of Religious Cultures and Secular Ethics into the secondary school program. The schools from 19 Russian regions began to study the subject as an experiment. Since September 1, 2012 the subject has been included into the curriculum of all Russian regional schools.

The subject consists of six modules: Orthodox Culture, Islam Culture, Buddhism Culture, Judaism Culture, World Religious Cultures, and Secular Ethics. The learners and their parents can choose one module in accordance with their wish.

The subject includes the following components: main notions of religious cultures, the history of religious cultures, the history of different cultures in Russia, features and traditions of religions, descriptions of sacred books, buildings, celebrations, and sacred objects.

The study of a new school subject had a wide public resonance. Russian society divided into two parts. One part supported it. The other part had a negative attitude to the subject. Researches from the Public Opinion Foundation (POF) discovered that $58 \%$ Orthodox people, $42 \%$ Muslims, and $25 \%$ nonbelievers have a good attitude to the new subject. $32 \%$ nonbelievers are indifferent to it. $31 \%$ unbelievers have a negative position. Researches think that a good attitude is motivated by the desire to cultivate kindness humanity and love in children. Many people believe that the subject can develop cultural (polite) behavior and better manners.

The analyst Georgiy Kertman says that we can explain that positions as a hope to increase the influence of the subject and the impact of belief. The majority of citizens believe in educational influence of a religion. Many speak about the importance of a religious knowledge, but it is difficult to develop the approach to teaching a new subject. If they say, for example, "children should know their religion," or "people should know about their belief," they see church fellowship probably. If they say "man should know different beliefs," or "to know about different religions," they think the subject does not concern religion. Approximately a quarter of people support the new subject with a hope to extend student's knowledge. Another quarter hopes to attract them to religion [7].

Does the study of this subject influence the formation of learners' religious motivation?

We investigated the question in September 2013. 700 students from Kursk State University and Kursk State Medical University were the respondents. Their average age is $18-20$ years old. The students attended the elective course of Orthodox Culture in secondary school.

The students were asked the following questions:

1) Do you believe in God?

2) Which religion do you belong to?

3) Do you consider your religion to be the only true?

4) Do you participate in church service or believer meetings?

5) Do you perform religious rites?

6) Do you pray?

7) What is your attitude to other religion representatives?

8) Do you preach your faith?

These are the following important research results:

1) $74 \%$ identified themselves as orthodox and they believe in God.

2) $36 \%$ considered all religions to be equal and $27 \%$ think "only my religion is truth."

3) $40 \%$ participate in church service only on church holidays and $54 \%$ have answered "another thing" (i.e., they participate seldom or do not participate at all).

4) $35 \%$ performed religious rites only on religious holidays and $42 \%$ have answered "another thing" (i.e., they perform religious rites seldom or do not perform at all).

5) $32 \%$ pray when they need it, $23 \%$ prayed from time to time, and $29 \%$ chose "another thing" (i.e., they do not prey probably).

6) $43 \%$ have a religious tolerance, $10 \%$ obey God's law, and $42 \%$ answered "indifferently."

7) $46 \%$ said that they speak about their faith and $44 \%$ have answered "another thing" (i.e., they do not speak about faith).

The results show that the elective subject Orthodox Culture did not aim at imposing religion. The subject tells about Orthodox in historical and cultural context. It attracts to the religious cultural knowledge, educates tolerance, an ability to have a dialogue with believers. Most important thing - it teaches to respect religion. Russian philosopher and academician Leo Mitrochin says: "Religion touches substantial foundations of human ontology, appeals to the contemporary needs, which could not be satisfied by science and secular knowledge. We can be skeptical or de facto, but there is an obvious fact-religion touches sacramental feelings and wishes of millions of people. Religion is a serious sphere and a deep respect to it is based on realistic understanding of substantial historical laws" [8].

It seems important to discuss this subject. Religious cultural studying provides a possibility to organize the new training system with the priority of mentality and morality, making an accent on religious values. In this case our school follows the best Russian educational traditions and meets 
modern requirements. Professor Vladimir Menshikov says: "We do the right thing choosing spiritual and moral training context. We have a chance to organize a lively spiritual and moral education. Today we have possibilities to organize mental and moral training system. Hence, we have a real chance to organize a new educational system" [9].

\section{EdUCATIONAL CONTROVERSIES}

Government policy consists of internal contradictions. Therefore $35 \%$ of Russians are sure that state educational actions "withdraw" the educational system away from optimal educational model of modern Russia. For example, there exists a controversy between the declared principle and its practical application. Still there are no single-valued meanings of main concepts in federal legislative system concerning the state educational policy. The state proclaims the guarantee of free education. With this aim it increases the expenses on free education, and it seems to be a necessary action. But Russian citizen's expenses increase, too. The sociologists say that fee-paid education is the most important problem in modern Russia. Somehow, it breaks the principle of accessible education, because high quality education becomes inaccessible for the most part of Russians, especially for vulnerable groups of society. In this case education builds up differentiation between various social layers.

On the other hand the researches Grigoriy Balychin, Anatoliy Berdashkevich, and Alexander Kalinin point out: "Payment for education in Russia is not high. It is lower than in other countries. But material-and-technical base does not correspond to international standards" [10]. The investigations show that $25 \%$ of schools are poorly equipped. Such schools are mainly situated in small towns and countryside. The parents, whose children visit these schools, usually don't have a university degree [11]. Such schools don't provide good education. They are not profitable and can be closed. For example, from 1990 to 2004 the government closed 3105 such schools [12]. So, nowadays, "a real threat of Russian educational potential decrease exists" [13].

The next contradiction is the absence of fixed criteria of educational principles that are proclaimed by the government. For example, secular principle of education is still not fixed. At the same time, the federal law On Education 2012 proclaims secular education, and federal law On Freedom of Religion 1993 foresees an opportunity of studying religion at school.

Professor Igor Metlik says: "Secular means a transmission of church, monastery property into the state property. Today this term determines religion freedom" [14]. From this opinion the understanding of secular education as a prohibition of learning religious subjects is not right. But Russian society has a stereotype of secular education as a prohibition of learning religious subjects at educational institutions. As a result, the new subject Foundations of Religious Cultures and Secular Ethics had many negative opinions because of such understanding of secular education.

The facts from the history of Russian education show that secular education was misunderstood, as the education that prohibits religious subjects at school. In pre-revolutionary Russia the presence of religious subjects in a curriculum of an educational institution was not a criterion for referring this institution to a confessional one. For example, in the 19 th century and the beginning of 20 th century the confessional institutions belonged to the Department of Orthodox Confession. They are seminaries, schools of theology, parochial schools. The other institutions were secular. Though, the subject The Law of God was taught obligatory, it didn't interfere the secular character of the institution. Secular institutions were named so according to the departments they belonged to: the Ministry of Education or municipal authorities [15].

In addition, European experience shows wrong understanding of secular education as prohibition of learning religious subjects, too. Professor Margarita Kostykova says: "European counties, for example, Germany and England are secular but poly-confessional states. Many Moslems immigrants live there, but national educational plans have a mandatory subject Religion. The state and confessions have different responsibilities in teaching and management. The educational right of each person is supported by a legislation. Thus, foreign experience shows that a mandatory religion subject is relevant to state secular education" [16].

\section{CONCLUSION}

The desire of Russian government to activate its role in educational sphere can be clearly observed during the last decade. The first, it is proved by the development of federal educational legislation that is very important for the regulation of educational sphere. The second, it is proved by numerous organizational events that are held by the government to implement educational priorities.

State educational priorities are: realization of educational right, general access and free education, educational quality, new training system development, social protection of educational specialists, social protection of learners, and financial education support. The realization of these priorities is supported by the creation of educational system that can respond to the demands and educational needs of Russian citizens.

At the same time, we can discover few discrepancies, explaining public dissatisfaction with the state educational policy. They reveal the necessity of the current federal legislation improvement. These measures will help to make Russian educational policy more effective.

\section{REFERENCES}

[1] N. Zorkay, Public Opinion-2012, Moscow: Levada-Center, 2012.

[2] B. N. Fiapshev, T. A. Fiapsheva, and A. B. Fiapshev, Dialectics of Russian Education, Rostov-on-Don: Rostizdat, 2007, ch. 2, pp. 266.

[3] D. A. Agofarov, Law and Regulation Supply of Education Educational System Law Regulation, Moscow: Vlados-Press, 2008.

[4] E. D. Dneprov, Education and Politics the Newest Political History of Russian Education, Moscow: Publishing house of Higher School of Economics, 2006, ch. 1, pp. 85.

[5] E. D. Dneprov, Education and Politics the Newest Political History of Russian Education, Moscow: Publishing house of Higher School of Economics, 2006, ch. 2, pp. 174-201.

[6] Russian Federation Code, Moscow: Russian President's Administration Law Library, 2012, pp. 17807-17934. 
[7] G. Kertman. (June 2013). Foundations of religious cultures and secular ethics. Trivial interpretations. Public Opinion Foundation. [Online]. 3. Available: http://fom.ru/blogs/10995/

[8] L. N. Mitrochin, Religion and Culture, Moscow: Institute of Philosophy Russian Academy of Science, 2000, p. 281.

[9] V. Menshikov, "Mental and moral education: subject, context and our children's future," Spiritual and Moral Education, vol. 4, pp. 3-25, April 2013.

[10] G. A. Balychin, A. P. Berdashkevict, and A. V. Kalinin, Educational System in Russia: Subjects and Objects of Legal Relations, State Regulation forms and Methods, Moscow: State Duma, 2009, pp. 196.

[11] V. I. Kuzminov, Education and Society: Is Russia Ready to Invest into its Future? Moscow: Publishing House of Higher School of Economics, 2007, pp. 8.

[12] B. N. Fiapshev, T. A. Fiapsheva, and A. B. Fiapshev, Dialectics of Russian Education, Rostov-on-Don: Rostizdat, 2007, ch. 1, pp. 214.

[13] V. I. Jhukov, At the Turn of Millenniums: Sociology of National Reforms (1985-2005), Moscow: Publishing House of State Russian Social University, 2008, pp. 683.

[14] I. V. Metlyk, Religion and Education in Secular School, Moscow: Planet-2000, 2004, pp. 27.

[15] M. S. Starodubtceva, Theory and Practice of the Church School in Russia from the Second Part of the 19th to Beginning of the 20th Centuries, Kursk: Kursk State University, 2004.

[16] M. N. Kostykova, Religion Training in Russian Educational System of 19th Century, Vladivostok: Far East University, 2001, pp. 9-10.

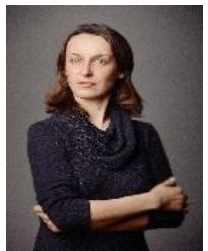

Marina Starodubtceva was born in Shigry, Kursk region, Russia in 1974. In 1996 she graduated from Philological Department Kursk State University, Kursk, Russia. Areas of specialization: Philology. Since 2001 Ph.D. Candidate. Areas of specialization:
Pedagogics, History of Pedagogics and Education. Since 2002 she was Lecturer, Senior Lecturer at Theology and Religion Studies Department of Kursk State University. Since 2006-Associate Professor. She leads annual summer courses for master's degree students in scientific and research work She has around 60 publications, including a monograph Theory and practice of the Church school in Russia from the second part of the 19 th to beginning of the 20 th centuries (Kursk: Kursk State University, 2004). She is a co-author of the innovative course book for 9 th grade school students The bases of Orthodox culture (Kursk: Kursk State University, 2012). Her current field of interests is metaphysics problems of religion Russian and European philosophy. Now she is preparing her doctoral thesis. She leads an active public life. She has been a curator of a regional program "Gifted children" for 7 years.

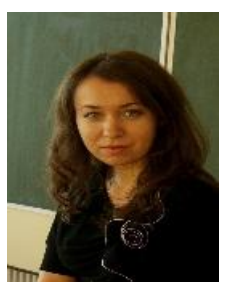

Irina Krivko was born on January 18, 1985 in Russia In 2007 she graduated from Kursk State University, the Faculty of Foreign Languages, Kursk, Russia. her fields of study include psycho-linguistics, theory of language, synergetics in linguistics, synonymic attraction. Since 2007, she was an assistant lecturer who teaches English, gives lectures in intercultural communication and professional translation. Since 2010, she was an assistant professor. In 2011 she received a Ph.D. Candidate degree in linguistics. She took part in various scientific conferences and published 14 academic papers. Scientific sphere of interests: individual and mental lexicon, synergetics and linguistics, chaotic systems, education, interrelation of complex chaotic structures. 